\title{
Purification and characterization of a novel RNase with antiproliferative activity from the mushroom Lactarius flavidulus
}

\author{
Yingying $\mathrm{Wu}^{1}$, Hexiang Wang ${ }^{1}$ and Tzibun $\mathrm{Ng}^{2}$
}

\begin{abstract}
A 14.6-kDa RNase, with a pH optimum of 5.5 and a temperature optimum of $70^{\circ} \mathrm{C}$, was isolated from dried fruiting bodies of the edible mushroom Lactarius flavidulus. The purification procedure involved, in succession, ion exchange chromatography on DEAE-cellulose, CM-cellulose and SP-Sepharose, and finally FPLC-gel filtration on Superdex 75. The RNase was adsorbed on all three ion exchangers. The ranking of its activity toward various polyhomoribonucleotides was poly(C) $>\operatorname{poly}(G)>\operatorname{poly}(A)>$ poly(U). It suppressed proliferation of HepG2 cells and L1210 cells with an IC $\mathrm{C}_{50}$ of $3.19 \mu \mathrm{m}$ and $6.52 \mu \mathrm{m}$, respectively. It also inhibited the activity of HIV-1 reverse transcriptase with an $\mathrm{IC}_{50}$ of $2.55 \mu \mathrm{M}$.
\end{abstract}

The Journal of Antibiotics (2012) 65, 67-72; doi:10.1038/ja.2011.112; published online 21 December 2011

Keywords: antiproliferative; Lactarius flavidulus; mushroom; RNase

\section{INTRODUCTION}

The literature on Lactarius flavidulus is limited to only two reports. Peranylphenols isolated from the mushroom were designated as flavidulols A, B and $\mathrm{C},{ }^{1-2}$ which displayed immunosuppressive activity on proliferation of mouse lymphocytes induced by Con A and lipopolysaccharide. ${ }^{2}$ The literature on other Lactarius species is more abundant but work related to proteins is confined to five papers on lectins and one paper on an enzyme. Panchak and Antonyuk described the purification of a lectin from fruiting bodies of L. pergamenus ${ }^{3}$ and $L$. rufus ${ }^{4}$ and another three lectins have been purified from $L$. deterrimus, ${ }^{5}$ L. lignyotus ${ }^{6}$ and $L$. deliciosus. ${ }^{7}$

RNases are found in a host of organisms. Barnase and binase are RNases purified from the bacteria Bacillus amiloliquefaciens and $B$. internedius, respectively. Despite similarities in structure and physicochemical and catalytic activities, the former is dependent on multifunctional Spo0A regulator controlling sporulation, biofilm formation and cannibalism, whereras binase is synthesized under phosphate starvation. Barnase and binase show some differences in practical applications. Both have been found to be useful in cancer research because of success in targeted delivery and selectivity towards tumor cells. ${ }^{8}$ Plant RNases can be used as antiproliferative agents targeting human tumors growing in mice. ${ }^{9}$ Onconase from the frog Rana pipiens has antitumor activity and clinical trials on patients with breast, kidney, lung and pancreatic cancers have been carried out. ${ }^{10}$ RNases have been isolated from a lot of mushrooms including portabella mushroom, ${ }^{11}$ Dictyophora indusiata, ${ }^{12}$ Hypsizigus marmoreus, ${ }^{13}$ Lyophyllum shimeiji, ${ }^{14}$ Pleurotus djamar, ${ }^{15}$ Pleurotus eryngii, ${ }^{16}$ Russula delica ${ }^{17}$ and Russulus virescens. ${ }^{18}$
Mushrooms are abundant in bioactive proteins encompassing lectins, antifungal proteins, ribosome inactivating proteins and RNases. ${ }^{16}$ RNases isolated from different mushroom species may have distinct $\mathrm{N}$-terminal sequences, $\mathrm{pH}$ and temperature optima, and polyhomoribonucleotide specificities. ${ }^{19}$ In view of this observation and the meager literature on the mushroom L. flavidulus in particular and on proteins from mushrooms of the Lactarius. genus in general, we set out to isolate a RNase from the edible mushroom L. flavidulus. Its biochemical characteristics and biological activities were compared with previously isolated RNases.

\section{MATERIALS AND METHODS}

\section{Isolation of RNase}

Dried L. flavidulus $(10 \mathrm{~g})$, an edible mushroom, was purchased in the Heilongjiang Province in China. The fruiting bodies were homogenized in distilled water $\left(20 \mathrm{ml} \mathrm{g}^{-1}\right)$. Following centrifugation of the homogenate at

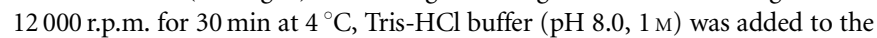
resulting supernatant until the concentration of Tris reached $10 \mathrm{~mm}$. The supernatant was fractionated by ion exchange chromatography on a $10 \mathrm{~cm} \times 100 \mathrm{~cm}$ column of DEAE-cellulose (Sigma, St Louis, MO, USA). After removal of the unadsorbed fraction D1, adsorbed proteins were desorbed stepwise with $50 \mathrm{~mm} \mathrm{NaCl}$ in the Tris- $\mathrm{HCl}$ buffer to yield fraction D2 and then with $300 \mathrm{~mm}$ and $1 \mathrm{M} \mathrm{NaCl}$ in the Tris-HCl buffer to yield fractions D3 and D4, respectively. Fraction D2 with RNase activity was then subjected to ion exchange chromatography on a $2.5 \mathrm{~cm} \times 30 \mathrm{~cm}$ column of CM-cellulose (Sigma) in 10 mм NaAc-HAc buffer ( $\mathrm{pH}$ 5.2). After removal of the unadsorbed fraction $\mathrm{C} 1$ with the same buffer, adsorbed proteins were eluted with $50 \mathrm{~mm}$ $\mathrm{NaCl}$ in the NaAc-HAc buffer to yield fraction $\mathrm{C} 2$ and then with $150 \mathrm{~mm}$ and $1 \mathrm{M} \mathrm{NaCl}$ in the Tris- $\mathrm{HCl}$ buffer to yield fractions $\mathrm{C} 3$ and $\mathrm{C} 4$, respectively.

${ }^{1}$ State Key Laboratory for Agrobiotechnology and Department of Microbiology, China Agricultural University, Beijing, China and ${ }^{2}$ School of Biomedical Sciences, Faculty of Medicine, The Chinese University of Hong Kong, Hong Kong, China

Correspondence: Professor H Wang or Professor T Ng, State Key Laboratory for Agrobiotechnology and Department of Microbiology, Agricultural University, Beijing 100193, China. E-mail: hxwang@cau.edu.cn or b021770@mailserv.cuhk.edu.hk

Received 26 August 2011; revised 30 October 2011; accepted 31 October 2011; published online 21 December 2011 
Fraction C3 with RNase activity was dialyzed and subsequently applied on a $1.0 \mathrm{~cm} \times 10 \mathrm{~cm}$ column of SP-Sepharose (GE Healthcare, Piscataway, NJ, USA) in $10 \mathrm{~mm}$ phosphate buffer ( $\mathrm{pH}$ 6.0). Unadsorbed proteins were eluted as fraction SP1 while adsorbed proteins were eluted as fractions SP2 with a linear $0-1 \mathrm{M} \mathrm{NaCl}$ concentration gradient. Fraction SP2 with RNase activity was dialyzed and subsequently further purified on a Superdex 75 HR 10/300 column (GE Healthcare) in $0.15 \mathrm{M} \mathrm{NH}_{4} \mathrm{HCO}_{3}$ buffer ( $\mathrm{pH}$ 8.5). The second resulting peak (SU2) represented purified RNase.

\section{Molecular mass determination by sodium dodecyl sulfate polyacrylamide gel electrophoresis and by FPLC-gel filtration} Sodium dodecyl sulfate polyacrylamide gel electrophoresis (SDS-PAGE) was carried out by following the procedure of Laemmli and Favre, ${ }^{20}$ using a $12 \%$ resolving gel and a 5\% stacking gel. At the end of electrophoresis, the gel was stained with Coomassie brilliant blue. FPLC-gel filtration was conducted using a Superdex 75 HR 10/30 column that had been calibrated with molecular-mass markers (GE Healthcare) using an AKTA Purifier (GE Healthcare). ${ }^{14}$

\section{Analysis of $\mathrm{N}$-terminal amino acid sequence}

Amino acid sequence analysis was performed using an HP G1000A Edman degradation unit and an HP1000 HPLC system (Hewlett-Packard, Palo Alto, CA, USA). ${ }^{17}$

\section{Assay for activity of RNase}

The activity of the purified RNase toward yeast tRNA (Sigma) was determined by measuring the formation of acid-soluble, UV-absorbing species with the method of Wang and Ng. ${ }^{21}$ The RNase was incubated with $200 \mu \mathrm{g}$ tRNA in $150 \mu \mathrm{g}$ of $100 \mathrm{~mm}$ MES buffer (pH 6.0) at $37^{\circ} \mathrm{C}$ for $15 \mathrm{~min}$. The reaction was stopped by addition of $350 \mu \mathrm{l}$ of ice-cold $3.5 \%$ perchloric acid and leaving the reaction mixture on ice for $15 \mathrm{~min}$. After centrifugation $(15000 \mathrm{~g}, 15 \mathrm{~min}$ ) at $4{ }^{\circ} \mathrm{C}$, the $\mathrm{OD}_{260}$ of the supernatant was determined after appropriate dilution. One unit of enzymatic activity is defined as the amount of enzyme that brings about an increase in $\mathrm{OD}_{260}$ of one per minute in the acid-soluble fraction per milliliter of reaction mixture under the specified condition.

\section{Effects of $\mathbf{p H}$ and temperature on RNase activity}

Citric acid- $\mathrm{Na}_{2} \mathrm{HPO}_{4}$ buffer $(\mathrm{pH} 2.2-8.0,0.1 \mathrm{M})$ was used to adjust the $\mathrm{pH}$ values of the reaction mixture. The effect of $\mathrm{pH}$ on the RNase activity was then determined. Incubation of the reaction mixture was carried out at different temperatures from $4-100^{\circ} \mathrm{C}$ to determine the effect of temperature on RNase activity. ${ }^{15}$

\section{Activity of RNase toward polyhomoribonucleotides}

The ribonucleolytic activity of the purified RNase toward polyhomoribonucleotides was assayed with a modification of the method of Wang and $\mathrm{Ng} .{ }^{22}$ Incubation of RNase with $100 \mu \mathrm{g}$ poly (A), poly (C), poly (G) or poly (U) in $250 \mu \mathrm{l}$ of $100 \mathrm{~mm}$ MES buffer ( $\mathrm{pH}$ 6.0) was performed at $37^{\circ} \mathrm{C}$ for $1 \mathrm{~h}$, before introduction of $250 \mu \mathrm{l}$ of ice-cold $1.2 \mathrm{~N}$ perchloric acid containing $20 \mathrm{~mm}$ lanthanum nitrate to stop the reaction. After leaving on ice for $15 \mathrm{~min}$, the sample was centrifuged at $15000 \mathrm{~g}$ for $15 \mathrm{~min}$ at $4{ }^{\circ} \mathrm{C}$. The absorbance of the supernatant, after appropriate dilution, was read at $260 \mathrm{~nm}$ (in case of poly (A), poly (G) and poly (U)) or at $280 \mathrm{~nm}$ (in case of poly (C)).

\section{Assay of antiproliferative activity on tumor cell lines}

Human hepatoma HepG2 and mouse leukemia L1210 cells were cultured in RPMI medium supplemented with $10 \%(\mathrm{v} / \mathrm{v})$ fetal bovine serum, $100 \mathrm{mgl}^{-1}$ streptomycin and $100 \mathrm{IU} \mathrm{ml}^{-1}$ penicillin, at $37^{\circ} \mathrm{C}$ in a humidified atmosphere of $5 \%(\mathrm{v} / \mathrm{v}) \mathrm{CO}_{2}$. Cells were subsequently seeded into 96 -well plates at a density of $2 \times 10^{3}$ cells per well, and incubated for $24 \mathrm{~h}$. Different concentrations of the L. flavidulus RNase in $100 \mu \mathrm{l}$ complete RPMI medium were then added to the wells and incubated for $72 \mathrm{~h}$. MTT quantification assays were then performed to measure the cell viability. Briefly, $20 \mu \mathrm{l}$ of a $5-\mathrm{mg} \mathrm{ml}^{-1}$ solution of [3-[4, 5dimethylthiazol-2-yl]-2,5-diphenyltetrazolium bromide] (MTT) in phosphate buffered saline was spiked into each well, and the plates were incubated for $4 \mathrm{~h}$. The plates were then centrifuged ( 2500 r.p.m., 5 min). The supernatant was removed, and $150 \mu$ l of dimethyl sulfoxide was added in each well to dissolve the MTT formazan at the bottom of the wells. Ten minutes later, the absorbance at $590 \mathrm{~nm}$ was determined with a microplate reader. PBS was added into wells instead of RNase as control. ${ }^{13}$

\section{Assay for HIV-1 reverse transcriptase (HIV-1 RT) inhibitory activity}

The assay for HIV-1 RT inhibitory activity was assessed by using an enzymelinked immunosorbent assay (ELISA) kit from Boehringer Mannheim (Germany). The assay took advantage of the ability of RT to synthesize DNA, starting from the template/primer hybrid poly (A) oligo $(\mathrm{dT})_{15}$. The digoxigenin- and biotin-labeled nucleotides in an optimized ratio were incorporated into one of the same DNA molecule, which was freshly synthesized by the RT. The detection and quantification of synthesized DNA as a parameter for RT activity followed sandwich ELISA protocol. Biotin-labeled DNA bound to the surface of microtiter plate modules that had been precoated with streptavidin. An antibody to digoxigenin, conjugated to peroxidase (anti-DIG-POD), subsequently bound to the digoxigenin-labeled DNA. Finally, the peroxidase substrate was added. The peroxidase enzymes catalyzed the cleavage of the substrate and produced a colored reaction product. The absorbance of the samples at $405 \mathrm{~nm}$ could be determined by using microtiter plate (ELISA) reader and was directly correlated to the level of RT activity. A fixed amount (4-6 ng) of recombinant HIV-1 RT was used. The inhibitory activity of the RNase was calculated as percentage inhibition as compared with a control without the protein. ${ }^{23}$

\section{RESULTS}

\section{Isolation of RNase}

Ion exchange chromatography of an extract of dried L. flavidulus fruit bodies on DEAE-cellulose resolved it into four fractions, an unadsorbed fraction D1 and three adsorbed fractions D2, D3 and D4. RNase activity was confined to fraction D2 (Table 1). Ion exchange chromatography of fraction D2 on CM-cellulose produced a small unadsorbed fraction $\mathrm{C} 1$, a much larger adsorbed fraction $\mathrm{C} 2$ and two large absorbed fractions C3 and C4. RNase activity was enriched in fraction C3 (Table 1). Fraction C3 was separated on SP-Sepharose into an unadsorbed fraction SP1 and an adsorbed fraction SP2 (Figure 1). The bulk of RNase activity resided in fraction SP2 (Table 1). Fraction SP2 was fractionated on Superdex 75 into two fractions, SU1 and SU2, (Figure 2). RNase activity was found only in fraction SU2 (Table 1).

Table 1 Yields and RNase activities of various chromatographic fractions of $L$. flavidulus (from $10 \mathrm{~g}$ dry fruiting bodies)

\begin{tabular}{|c|c|c|c|c|c|}
\hline Fraction & Yield (mg) & Specific activity $\left(U \mathrm{mg}^{-1}\right)$ & Total activity (U) & Recovery of activity (\%) & Purification fold \\
\hline Extract & 3018.9 & $2.1 \times 10^{4}$ & $6.2 \times 10^{7}$ & 100 & 1 \\
\hline D2 & 452.9 & $9.0 \times 10^{4}$ & $4.1 \times 10^{7}$ & 65.5 & 4.4 \\
\hline C3 & 42.9 & $4.0 \times 10^{5}$ & $1.7 \times 10^{7}$ & 27.4 & 19.2 \\
\hline SP2 & 5.8 & $2.5 \times 10^{6}$ & $1.5 \times 10^{7}$ & 23.2 & 120.9 \\
\hline SU2 & 3.6 & $3.3 \times 10^{6}$ & $1.2 \times 10^{7}$ & 19.0 & 159.6 \\
\hline
\end{tabular}




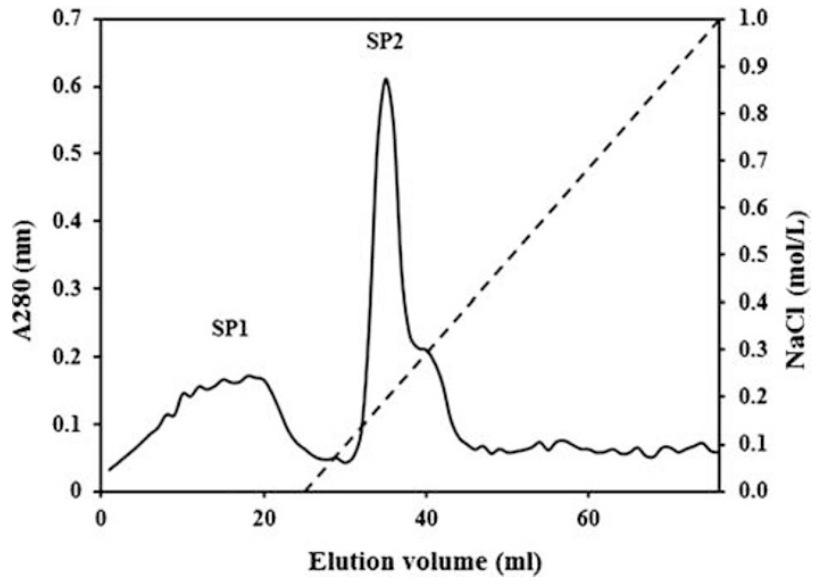

Figure 1 Ion exchange chromatography on SP-Sepharose. Sample: fraction C3, which was adsorbed on CM-cellulose. Column dimensions: $2.5 \mathrm{~cm} \times 30 \mathrm{~cm}$. Starting buffer: $10 \mathrm{~mm} \mathrm{Hac}-\mathrm{NaAc}(\mathrm{pH} 5.2)$. Slanting dotted line across the right side of the chromatogram represents linear $0-1 \mathrm{~m} \mathrm{NaCl}$ gradient used to elute adsorbed proteins.

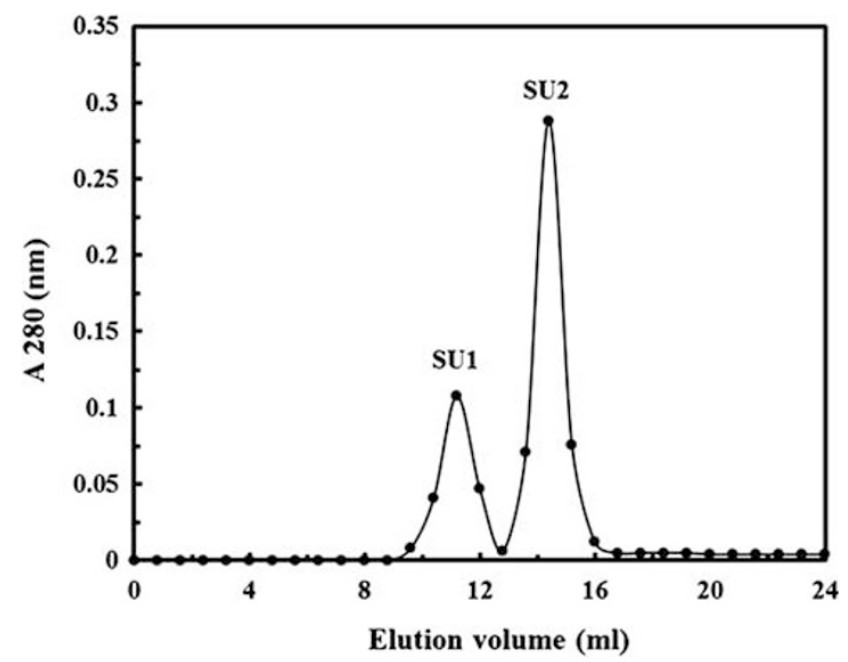

Figure 2 FPLC-gel filtration of fraction SP2 on a Superdex 75 HR10/30 column. Buffer: $0.2 \mathrm{~m} \mathrm{NH}_{4} \mathrm{HCO}_{3}(\mathrm{pH} 8.5)$. Flow rate: $0.5 \mathrm{ml} \mathrm{min}^{-1}$. Fraction size: $0.8 \mathrm{ml}$.

\section{Molecular mass determination}

Fraction SU2 displayed a molecular mass of $14.6 \mathrm{kDa}$ in gel filtration on Superdex 75 (Figure 2) and a single band with the same molecular mass in SDS-PAGE (Figure 3).

\section{$N$-terminal sequence}

The $N$-terminal sequence of the purified RNase is ATFVATIATNTLGTN. It exhibited little similarity to counterparts from other mushrooms (Table 2).

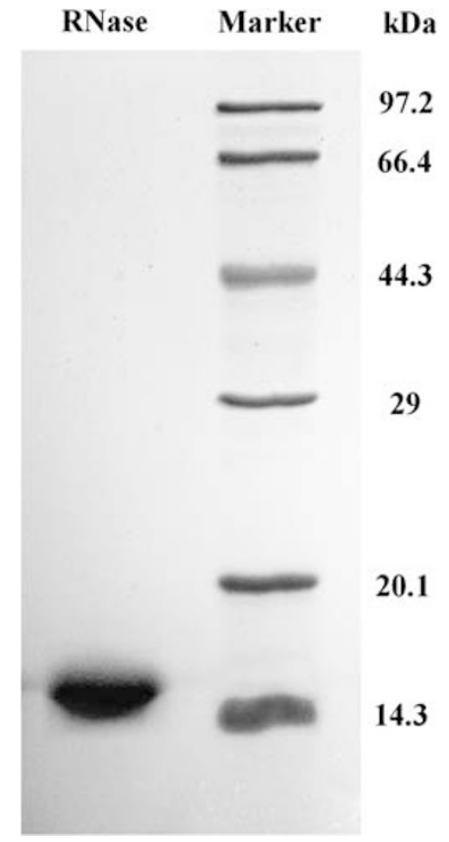

Figure 3 SDS-PAGE of purified L. flavidulus RNase (fraction SU2). The molecular mass of the marker proteins are, from top downward, 97.2, $66.4,44.3,29,20.1$ and $14.3 \mathrm{kDa}$. The molecular mass of SU2 was $14.6 \mathrm{kDa}$.

Table $2 \mathrm{~N}$-terminal sequence of $L$. flavidulus (LF) RNase in comparison with RNases from other mushrooms

\begin{tabular}{lll}
\hline Mushroom & N-terminal sequence & Reference \\
\hline LF & ATFVATIATNTLGTN & This paper \\
AB & ACAANNAARRYASSVGNNN & 11 \\
CM & ETAHTHAGIQYSTVDVNNSIMKAVGGGAGN & 36 \\
DI & GQPRQPQPQLLV & 12 \\
GL & HLPBVPSFAYGSIKVYIN & 37 \\
IL & VNSGCGTSGAESCSNSDDGTCCFEAPGGLL & 28 \\
LE & ISSGCGTTGALSCSSNAKGTCCFEAPGGLI & 29 \\
PE & GEVVQYYP & 16 \\
PO & ETGVRSCNCAGRSFTGTDVTNAIRSARAGGSGN & 31 \\
PP & AISANNERKGVNQQSVQNTYQENDV & 24 \\
PS & DNGEAGRAAR & 30 \\
PT & ALTAQDNRVRVGNRIVGNNFNFAAVQAAYY & 22 \\
RV & TDHTLDTMMTHTLRD & 18 \\
TG & DADIAVWAPPVNAQN & 27 \\
\hline
\end{tabular}

portabella mushroom (AB), Clitocybe maxima (CM), Dictyophora indusiata (DI), Ganoderma lucidum (GL), Irpex lacteus (IL), Lentinus edodes (LE), Pleurotus eryngii (PE), Pleurotus ostreatus (PO), Pleurotus pulmonarius (PP), Pleurotus sajor-caju (PS), Pleurotus tuber-regium (PT), Russulus virescens (RV), Thelephora ganbajun (TG). The bold text emphasizes the $\mathrm{N}$-terminal sequence of the RNase described in this paper.

\section{Optimum $\mathrm{pH}$ and temperature}

The activity of the purified RNase was maximum at $\mathrm{pH}$ 5.5. The activity of the RNase increased steadily from $\mathrm{pH} 3.0$ until it reached its maximum at $\mathrm{pH} 5.5$, and decreased steadily from $\mathrm{pH} 5.5$ until it reached residual level at $\mathrm{pH} 8.0$ (Figure 4). The activity fell precipitously when the temperature was raised from $70-90^{\circ} \mathrm{C}$. The activity observed at $100^{\circ} \mathrm{C}$ was similar to that at $37^{\circ} \mathrm{C}$ (Figure 5). 


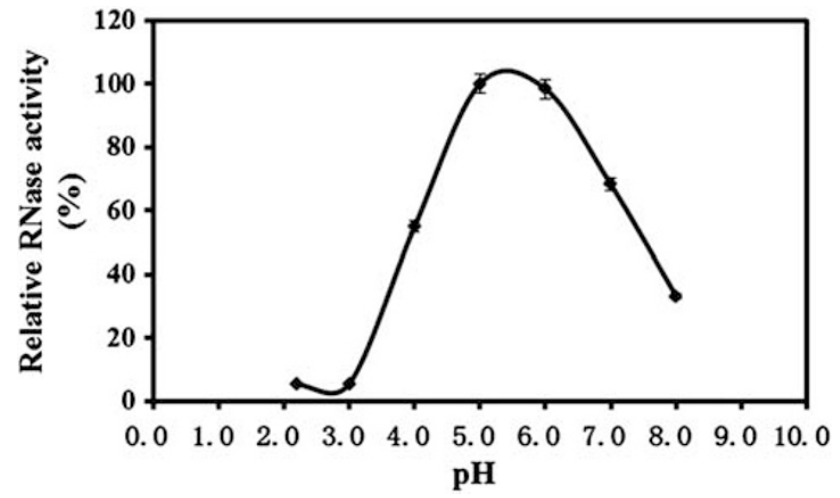

Figure $4 \mathrm{pH}$ dependence of L. flavidulus RNase. Temperature used: $37^{\circ} \mathrm{C}$. Duration of incubation: $15 \mathrm{~min}$. Buffer concentration: $0.1 \mathrm{~m}$.

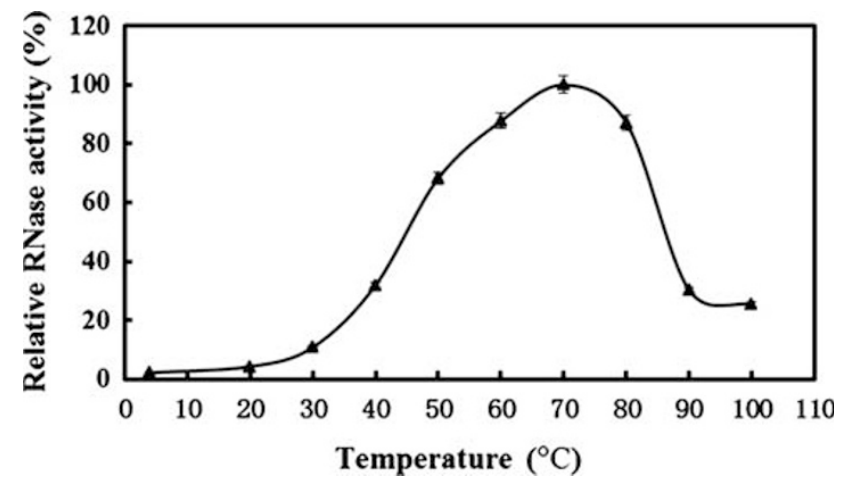

Figure 5 Temperature dependence of $L$. flavidulus RNase. Buffer used: $\mathrm{pH}$ 4.6, $0.1 \mathrm{~m} \mathrm{Hac}-\mathrm{NaAc}$ buffer. Duration of incubation: $15 \mathrm{~min}$.

Table 3 Inhibition rate (\%) of L. flavidulus RNase on HepG2 cells, L1210 cells and HIV-1 RT

\begin{tabular}{lccccc}
\hline \multicolumn{5}{c}{ Inhibition (\%) } \\
\cline { 2 - 5 } & $10 \mu \mathrm{M}$ & $5 \mu \mathrm{M}$ & $2.5 \mu \mathrm{M}$ & $1.25 \mu \mathrm{M}$ & \multirow{2}{*}{ IC $_{50}(\mu \mathrm{m})$} \\
\hline HIV-1 RT & $83.5 \pm 7.4$ & $71.3 \pm 6.6$ & $54.1 \pm 5.7$ & $34.6 \pm 3.6$ & 2.55 \\
Hep G2 & $78.4 \pm 7.1$ & $67.2 \pm 6.9$ & $52.6 \pm 5.4$ & $30.7 \pm 4.1$ & 3.19 \\
L1210 & $66.3 \pm 6.3$ & $49.7 \pm 4.8$ & $28.0 \pm 3.3$ & $13.9 \pm 2.0$ & 6.52 \\
\hline
\end{tabular}

Results represent mean \pm s.d. $(N=3)$

Polyhomoribonucleotide specificity

The RNase exerted a specific ribonucleolytic activity of 25.8, 3.5, 78.1 and $102.4 \mathrm{U} \mathrm{mg}^{-1}$ toward poly (A), poly (U), poly (G) and poly (C), respectively.

\section{Antiproliferative activity on cancer cells}

Proliferation of the cancer cell lines HepG2 and L1210 was inhibited by the RNase, with $\mathrm{IC}_{50}$ values of $3.19 \mu \mathrm{M}$ and $6.52 \mu \mathrm{M}$, respectively (Table 3).

\section{HIV-1 reverse transcriptase inhibitory activity}

The purified RNase inhibited HIV-1 reverse transcriptase, with an $\mathrm{IC}_{50}$ value of $2.55 \mu \mathrm{M}$. (Table 3 ).

\section{DISCUSSION}

L. flavidulus mushroom RNase has a molecular mass $(14.6 \mathrm{kDa})$ in the vicinity of those of Lyophyllum shimeiji $(14.5 \mathrm{kDa}),{ }^{14}$ Pleurotus pulmonarius $^{24}$ and Agaricus bisporus RNases $(14 \mathrm{kDa})^{11}$ and P. eryngii RNase $(16 \mathrm{kDa}){ }^{16}$ It is larger than that of $P$. ostreatus RNase $(9 \mathrm{kDa})^{25}$ but smaller than those of Russula virescens RNase $(28 \mathrm{kDa}){ }^{18}$ P. tuber-regium RNase $(29 \mathrm{kDa}){ }^{26}$ Thelephora ganbajum RNase $(30 \mathrm{kDa})^{27}$ and straw mushroom RNase $(42.5 \mathrm{kDa}) .{ }^{21}$

L. flavidulus RNase is characterized by an $N$-terminal sequence distinctly different from those of previously reported RNases of mushroom, plant and animal origins. It is noteworthy that RNases of very few mushrooms except those of Irpex lactius and Lentinus edodes exhibit pronounced sequence homology. ${ }^{28-29}$

The optimum $\mathrm{pH}$ ( $\mathrm{pH}$ 5.5) for L. flavidulus RNase is different from $\mathrm{pH} 4.5$ for portabella mushroom ${ }^{11}$ and $R$. virescens RNases, ${ }^{18}$ and pH 8.0 for P. pulmonarius. ${ }^{24}$

L. flavidulus RNase is markedly more thermostable than T. ganbajun RNase. In the latter RNase, activity is much attenuated at $80^{\circ} \mathrm{C}$ compared with that at $20^{\circ} \mathrm{C}$ and is indiscernible at $100{ }^{\circ} \mathrm{C}^{27}$ On the other hand, the activity of $L$. flavidulus RNase was unaltered at $90{ }^{\circ} \mathrm{C}$, thus it is a thermostable RNase.

L. flavidulus $\mathrm{RNase}$ is specific for poly $(\mathrm{C})$. RNases from $R$. virescens $^{18}$ and Termitomyces globulus ${ }^{27}$ manifest co-specificity for poly(A) and poly $(\mathrm{C})$. Portabella mushroom RNase exhibits ribonucleolytic activity toward poly $(\mathrm{A})$, poly $(\mathrm{C})$ and $\operatorname{poly}(\mathrm{U}) .{ }^{11}$ L. sajor-caju RNase is poly $(\mathrm{U})$-specific. ${ }^{30}$ On the other hand, P. tuber-regium ${ }^{22}$ and P. ostreatus ${ }^{31}$ RNases are specific for poly $(\mathrm{G})$.

Like other mushroom RNases, L. flavidulus RNase exhibits antiproliferative activity towards HepG2 and L1210 cells, and inhibits the activity of HIV-1 reverse transcriptase. However, the potencies of the antiproliferative and HIV-1 reverse transcriptase inhibitory activities are higher than those of the majority of other mushrooms reported previously. ${ }^{32}$

RNase-controlled RNA degradation is a determining factor in the control of gene expression, maturation and turnover, which are further associated with the progression of cancers and infectious diseases. Fang and $\mathrm{Ng}^{32}$ presented a review of the representative RNases of fungal, bacterial, plant and animal origins and outlined their potential medicinal value in the treatment of tumor and AIDS. Among them, the most clinically promising RNases are mushroom RNases, binase and barnase from bacteria, ginseng RNases and onconase from frog $(R$. pipiens). Fast developing protein engineering of RNase, which displays more potent cytotoxic activity and greater selectivity for malignant cells, has also aroused the interest of researchers. The multiple anticancer mechanisms of RNase are also included.

It is likely that the antiproliferative activity demonstrated herein is correlated with antitumor activity in vivo as reported in the literature. The $\mathrm{IC}_{50}$ values $(24 \mathrm{~h})$ of Momodica charantia lectin (MCL) for nasopharygeal carcinoma cells CNE-1 and CNE-2 cells were $6.9 \pm 0.2 \mu \mathrm{M}$ and $7.4 \pm 0.4 \mu \mathrm{M}$, respectively. Treatment with $1 \mathrm{mg}$ M. charantia lectin per $\mathrm{kg}$ body weight for 12 consecutive days (i.p., $1.0 \mathrm{mg} \mathrm{kg}^{-1}$ per day) resulted in nearly $45 \%$ reduction of tumor volume. ${ }^{33}$ Russula lepida lectin exhibited antiproliferative activity toward hepatoma HepG2 cells and human breast cancer MCF-7 cells with an $\mathrm{IC}_{50}$ of $1.6 \mathrm{~mm}$ and $0.9 \mathrm{~mm}$, respectively. Daily i.p. injections of $R$. lepida lectin $\left(5.0 \mathrm{mg} \mathrm{kg}^{-1}\right.$ body weight per day for 20 days) brought about $67.6 \%$ reduction in the weight of S-180 tumor. $^{34}$ The anti-HIV reverse transcriptase activity shown in the present study is also likely to be meaningful regarding inhibition of HIV in view of the following findings. Balzarini et al. ${ }^{35}$ reported that the mannose-specific lectins from Cymbidium hybrid, Epiactis 
Table 4 Comparison of characteristics of RNases from L. flavidulus and other mushrooms

\begin{tabular}{|c|c|c|c|c|c|c|c|c|}
\hline Mushroom & $\begin{array}{l}\text { Absorbed ion } \\
\text { exchange }\end{array}$ & $\begin{array}{l}\text { Molecular } \\
\text { mass (kDa) }\end{array}$ & $\begin{array}{l}\text { Optimum } \\
\text { pH }\end{array}$ & $\begin{array}{c}\text { Optimum } \\
\text { temperature }\left({ }^{\circ} \mathrm{C}\right)\end{array}$ & $\begin{array}{l}\text { Polyhomorib- } \\
\text { onucleotide specificity }\end{array}$ & $\begin{array}{c}\text { Antiproliferative activity } \\
\text { toward cancer cells }\end{array}$ & $\begin{array}{c}H I V-1 \quad R T \\
\text { inhibitory activity }\end{array}$ & References \\
\hline LF & $\begin{array}{l}\text { DEAE-cellulose } \\
\text { CM-cellulose } \\
\text { SP-Sepharose }\end{array}$ & 14.6 & 5.5 & 70 & Poly(C) & + & + & This paper \\
\hline$A B$ & $\begin{array}{l}\text { DEAE-cellulose } \\
\text { CM-cellulose }\end{array}$ & 14 & 4.5 & 60 & Poly(A) & ND & ND & 11 \\
\hline DI & $\begin{array}{l}\text { DEAE-cellulose } \\
\text { CM-cellulose } \\
\text { Q-Sepharose }\end{array}$ & 28 & $4.0-4.5$ & 60 & Poly(U) & ND & ND & 12 \\
\hline $\mathrm{HM}$ & $\begin{array}{l}\text { CM-cellulose } \\
\text { Q-Sepharose }\end{array}$ & 18 & 5.0 & 70 & Poly(C) & + & ND & 13 \\
\hline LS & $\begin{array}{l}\text { DEAE-cellulose } \\
\text { Q-Sepharose } \\
\text { SP-Sepharose }\end{array}$ & 14.5 & 6.0 & 70 & Poly(U) & + & + & 14 \\
\hline PE & $\begin{array}{l}\text { DEAE-cellulose } \\
\text { Affi-gel blue gel } \\
\text { SP-Sepharose }\end{array}$ & 16 & 6.5 & 70 & Poly(A) & ND & ND & 16 \\
\hline PO & $\begin{array}{l}\text { CM-cellulose } \\
\text { Mono S }\end{array}$ & 12 & 7.0 & 55 & Poly(U) & ND & ND & 38 \\
\hline PP & $\begin{array}{l}\text { Affi-gel blue gel } \\
\text { CM-cellulose } \\
\text { Mono S }\end{array}$ & 14.4 & 7.0 & 55 & Poly(C) & ND & ND & 24 \\
\hline $\mathrm{RD}$ & $\begin{array}{l}\text { DEAE-cellulose } \\
\text { SP-Sepharose } \\
\text { Q-Sepharose }\end{array}$ & 14 & 5.0 & 60 & Poly(C) & + & ND & 17 \\
\hline
\end{tabular}

Abbreviation: ND, not determined.

portabella mushroom (AB), Clitocybe maxima (CM), Dictyophora indusiata (DI), Hypsizigus marmoreus (HM), Lyophyllum shimeiji (LS), Pleurotus djamar (PD), Pleurotus eryngii (PE), Pleurotus ostreatus (PO), Pleurotus pulmonarius (PP), Russula delica (RD), Russulus virescens (RV), Thelephora ganbajun (TG).

helleborine and Listeria ovata and the $\mathrm{N}$-acetylglucosamine-specific lectin from Urticadioica potently and selectively inhibited HIV-I and HIV-2 in MT-4 cells. The C. hybrid and E. helleborine lectins had an $\mathrm{IC}_{50}$ of $40-80 \mathrm{ng} \mathrm{ml}^{-1}$, whereas the $U$. dioica lectin had an $\mathrm{IC}_{50}$ value of $0.3-9 \mathrm{pg} \mathrm{ml}^{-1}$.

L. flavidulus RNase is a new protein as suggested by the novel $\mathrm{N}$-terminal sequence. It has some novel characteristics including activity at high temperatures, and a $\mathrm{pH}$ optimum and base specificity different from some of the isolated mushroom RNases (Table 4). It exhibits antiproliferative activity, toward tumor cells, and anti-HIV-1 reverse transcriptase activity, which have not been demonstrated for the majority of the isolated mushroom RNases.

\section{CONFLICT OF INTEREST}

The authors declare no conflict of interest.

\section{ACKNOWLEDGEMENTS}

This work was financially supported by National Grants of China (2010CB732202).
1 Takahashi, A., Kusano, G., Ohta, T. \& Nozoe, S. The constituents of Lactarius flavidulus. Imai. Chem. Pharm. Bull. (Tokyo) 7, 2366-2370 (1988).

2 Fujimoto, H., Nakayama, Y. \& Yamazaki, M. Identification of immunosuppressive components of a mushroom, Lactarius flavidulus. Chem. Pharm. Bull. 4, 654-658 (1993).

3 Panchak, L. V. \& Antonyuk, V. O. Purification of a lectin from fruit bodies of Lactarius pergamenus (fr.) Fr. and studies of its properties. Biochemistry (Mosc) 4, 438-449 (2011).

4 Panchak, L. V. \& Antoniuk, V. O. Purification of lectin from fruiting bodies of Lactarius rufus (scop.: Fr.)Fr. and its carbohydrate specificity. Ukr. Biokhim. Zh. 2, 123-128 (2007).

5 Giollant, M. et al. Characterization of a lectin from Lactarius deterrimus (research on the possible involvement of the fungal lectin in recognition between mushroom and spruce during the early stages of mycorrhizae formation). Plant. Physiol. 2, 513-522 (1993).

6 Sychrova, H., Ticha, M. \& Kocourek, J. Studies on lectins. Lix. Isolation and properties of lectins from fruiting bodies of Xerocomus chrysenteron and Lactarius lignyotus. Can. J. Biochem. Cell. Biol. 7, 700-704 (1985).

7 Guillot, J., Giollant, M., Damez, M. \& Dusser, M. Isolation and characterization of a lectin from the mushroom, Lactarius deliciosus. J. Biochem 6, 840-845 (1991).

8 Ulyanova, V., Vershinina, V. \& Ilinskaya, O. Barnase and binase: twins with distinct fates. FEBS. J. (2011).

9 Matousek, J. \& Matousek, J. Plant ribonucleases and nucleases as antiproliferative agents targeting human tumors growing in mice. Recent. Pat. DNA. Gene. Seq. 1, 29-39 (2010). 
10 Zwolinska, M. \& Smolewski, P. Onconase: a ribonuclease with antitumor activity. Postepy. Hig. Med. Dosw. (Online), 58-66 (2010)

11 Wang, H. X. \& Ng, T. B. A novel ribonuclease from fresh fruiting bodies of the portabella mushroom Agaricus bisporus. Biochem. Cell. Biol. 2, 178-183 (2006).

12 Wang, H. \& Ng, T. B. A novel ribonuclease from the veiled lady mushroom Dictyophora indusiata. Biochem. Cell. Biol. 6, 373-377 (2003).

13 Guan, G. P., Wang, H. X. \& Ng, T. B. A novel ribonuclease with antiproliferative activity from fresh fruiting bodies of the edible mushroom Hypsizigus marmoreus. Biochim. Biophys. Acta. 12, 1593-1597 (2007).

14 Zhang, R. Y., Zhang, G. Q., Hu, D. D., Wang, H. X. \& Ng, T. B A novel ribonuclease with antiproliferative activity from fresh fruiting bodies of the edible mushroom Lyophyllum shimeiji. Biochem. Genet. 7-8, 658-668 (2010).

$15 \mathrm{Wu}$, X., Zheng, S., Cui, L., Wang, H. \& Ng, T. B. Isolation and characterization of a novel ribonuclease from the pink oyster mushroom Pleurotus djamor. J. Gen. Appl. Microbiol. 3, 231-239 (2010)

$16 \mathrm{Ng}, \mathrm{T}$. B. \& Wang, H. X. A novel ribonuclease from fruiting bodies of the common edible mushroom Pleurotus eryngii. Peptides 8, 1365-1368 (2004).

17 Zhao, S. et al. An antiproliferative ribonuclease from fruiting bodies of the wild mushroom Russula delica. J. Microbiol. Biotechnol. 4, 693-699 (2010).

18 Wang, H. \& Ng, T. B. A ribonuclease with distinctive features from the wild green-headed mushroom Russulus virescens. Biochem. Biophys. Res. Commun. 4, 965-968 (2003).

$19 \mathrm{Ng}, \mathrm{T}$. B. Peptides and proteins from fungi. Peptides 6, 1055-1073 (2004).

20 Laemmli, U. K. \& Favre, M. Maturation of the head of bacteriophage T4. I. DNA packaging events. J. Mol. Biol. 4, 575-599 (1973).

21 Wang, H. \& Ng, T. B. Isolation of a new ribonuclease from fresh fruiting bodies of the straw mushroom. Biochem. Biophys. Res. Commun. 3, 714-718 (1999).

22 Wang, H. X. \& Ng, T. B. Purification and characterization of a potent homodimeric guanine-specific ribonuclease from fresh mushroom (Pleurotus tuber-regium) sclerotia. Int. J. Biochem. Cell. Biol. 5, 483-490 (2001).

23 Zhang, G. Q., Sun, J., Wang, H. X. \& Ng, T. B. A novel lectin with antiproliferative activity from the medicinal mushroom Pholiota adiposa. Acta. Biochim. Pol. 3, 415-421 (2009).

24 Ye, X. Y. \& Ng, T. B. A novel and potent ribonuclease from fruiting bodies of the mushroom Pleurotus pulmonarius. Biochem. Biophys. Res. Commun. 2, 857-861 (2002).
25 Ye, X. Y. \& Ng, T. B. A novel peptide with ribonuclease and translation-inhibitory activities from fruiting bodies of the oyster mushroom Pleurotus ostreatus. J. Pept. Sci. 6, 235-240 (2002).

26 Wang, H. X., Ng, T. B. \& Ooi, V. E. A ribonuclease from sclerotia of the edible mushroom Pleurotus tuber-regium. Biochem. Biophys. Res. Commun. 3, 544-546 (1998).

27 Wang, H. X. \& Ng, T. B. Purification of a novel ribonuclease from dried fruiting bodies of the edible wild mushroom Thelephora ganbajun. Biochem. Biophys. Res. Commun. 2, 855-859 (2004).

28 Watanabe, $\mathrm{H}$. et al. Base non-specific acid ribonuclease from irpex lacteus, primary structure and phylogenetic relationships in RNase T2 family enzyme. Biosci. Biotechnol. Biochem. 11, 2097-2103 (1995).

29 Kobayashi, H. et al. A new type of RNase T2 ribonuclease in two basidiomycetes fungi, Lentinus edodes and Irpex lacteus. Biosci. Biotechnol. Biochem. 10, 2307-2310 (2003).

30 Ngai, P. H. \& Ng, T. B. A ribonuclease with antimicrobial, antimitogenic and antiproliferative activities from the edible mushroom Pleurotus sajor-caju. Peptides 1, 11-17 (2004).

31 Nomura, $\mathrm{H}$. et al. Purification and primary structure of a new guanylic acid specific ribonuclease from Pleurotus ostreatus. J. Biochem. 1, 26-33 (1994).

32 Fang, E. F. \& Ng, T. B. Ribonucleases of different origins with a wide spectrum of medicinal applications. Biochim. Biophys. Acta. 1, 65-74 (2011).

33 Fang, E. F. et al. Momordica charantia lectin, a type II ribosome inactivating protein, exhibits antitumor activity toward human nasopharyngeal carcinoma cells in vitro and in vivo. Cancer. Prev. Res. (Phila) e-pub ahead of print (2011).

34 Zhang, G., Sun, J., Wang, H. \& Ng, T. B. First isolation and characterization of a nove lectin with potent antitumor activity from a Russula mushroom. Phytomedicine 10, 775-781 (2010).

35 Balzarini, J. et al. The mannose-specific plant lectins from Cymbidium hybrid and Epipactis helleborine and the (n-acetylglucosamine)n-specific plant lectin from Urtica dioica are potent and selective inhibitors of human immunodeficiency virus and cytomegalovirus replication in vitro. Antiviral. Res. 2, 191-207 (1992).

36 Wang, H. \& Ng, T. B. Isolation of a new ribonuclease from fruiting bodies of the silver plate mushroom Clitocybe maxima. Peptides 6, 935-939 (2004).

37 Wang, H. X., Ng, T. B. \& Chiu, S. W. A distinctive ribonuclease from fresh fruiting bodies of the medicinal mushroom Ganoderma lucidum. Biochem. Biophys. Res. Commun. 2, 519-522 (2004)

$38 \mathrm{Ye}, \mathrm{X}$. Y. \& Ng, T. B. Purification and characterization of a new ribonuclease from fruiting bodies of the oyster mushroom Pleurotus ostreatus. J. Pept. Sci. 2, 120-124 (2003) 